\title{
Effect of Grafting Time on Growth and Success Rate of Guava (Psidium guajava L.) Wedge Grafts Grown under Shade Net and Poly House Conditions
}

\author{
L. Vanaja*, D.V. Swami, B. Prasanna Kumar and P. Subbaramamma \\ College of Horticulture, Dr. Y.S.R. Horticultural University, Venkataramannagudem, \\ West Godavari District-534101, A.P., India \\ *Corresponding author
}

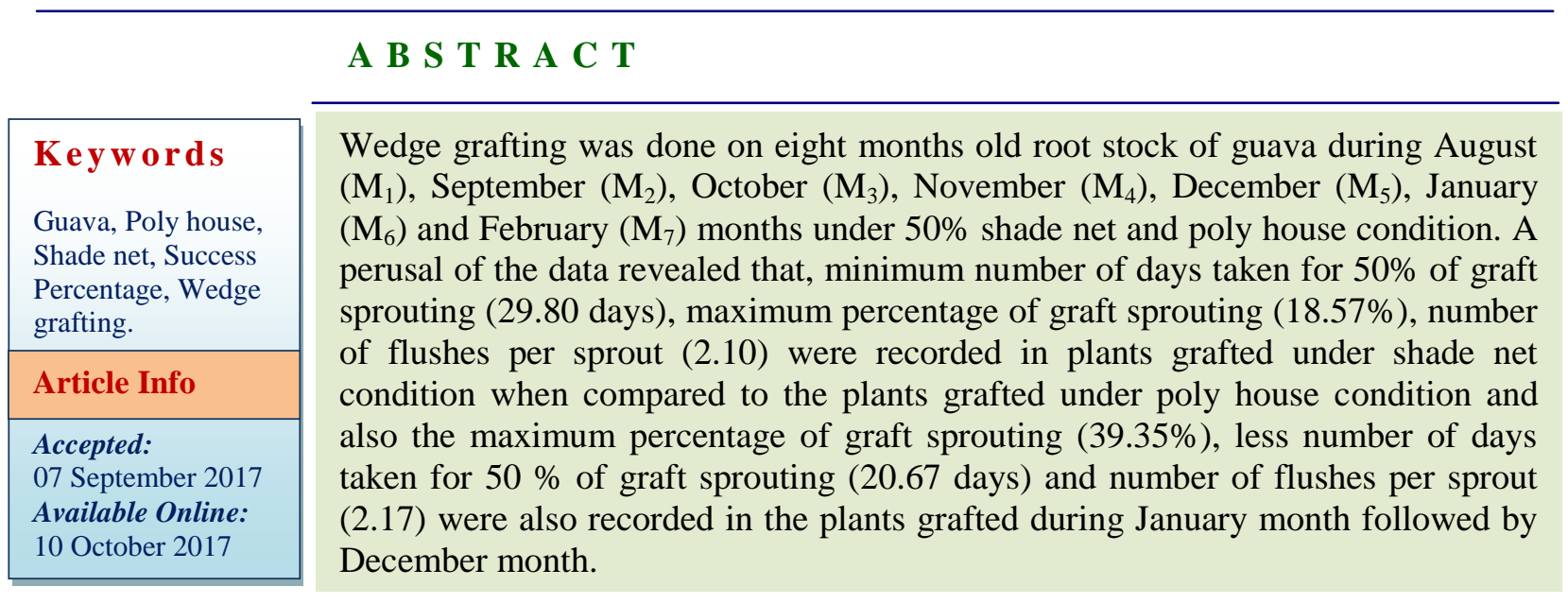

\section{Introduction}

Guava (Psidium guajava L.), is the poor man's apple and "apple of tropics" belongs to the family Myrtaceae, is one of the most important and legendary fruit of India and gradually became a crop of commercial significance in several other countries because of its hardy nature, prolific bearing, high vitamin-C content and more remunerative even without much care.

Guava is highly cross pollinated crop and the seed being a heterozygous in nature, it is not possible to get true-to-type plants through seeds. The planting material is the best requirement for any fruit crop because it influences the ultimate yield both in terms of quality and quantity (Singh et al., 2005).

In the present context, use of rapid multiplication methods become very important when planting material was limited for improved varieties or clones. Though, guava is propagated through air-layering, stooling, grafting and inarching and still not commercially viable due to varying rates of success due to absence of tap root system and involving cumbersome process for its multiplication. Keeping in view of these facts, the present investigation was carried out to find out the response of wedge grafting in 
different months of the year to assess the success of wedge grafting under shade net and poly house conditions.

\section{Materials and Methods}

The present investigation was carried during 2014-2015 at the Horticultural College and Research Institute, Venkataramannagudem, West Godavari District, Andhra Pradesh. Wedge grafting was performed during seven months, viz., August $\left(\mathrm{M}_{1}\right)$, September $\left(\mathrm{M}_{2}\right)$, October $\left(\mathrm{M}_{3}\right)$, November $\left(\mathrm{M}_{4}\right)$, December $\left(\mathrm{M}_{5}\right)$, January $\left(\mathrm{M}_{6}\right)$ and February $\left(\mathrm{M}_{7}\right)$ under $50 \%$ shade net as well as in poly house conditions. There were fourteen treatment combinations replicated thrice in a Factorial Randomized Block Design.

\section{Procedure of wedge grafting}

The grafting was done on 6-8 months old rootstock, which has attained a stem girth of $0.5-1 \mathrm{~cm}$. The scion shoots of $15 \mathrm{~cm}$ long of pencil thickness $(0.5 \mathrm{~cm})$ with 4 healthy buds were selected for grafting. Selected scions were defoliated on the mother plant, about one week prior to grafting.

At the same time apical growing portion of selected shoots was also beheaded, which helped in forcing the dormant grafts to swell. In this way, the grafts on the scion were ready to start sprouting at the time of grafting. The scion stick was inserted into the split of the stock and pressed properly so that cambium tissue of rootstock and scion could come into contact with each other. The procedure of wedge grafting sequential steps is shown in figure 1 .

The observations were recorded on success of grafting such as number of days taken for graft sprouting, per cent of graft sprouting, number of flushes per sprout and per cent of graft survival.
Number of days taken for 50 per cent of graft sprouting

The number of days taken for 50 percent of the grafts to sprout was counted in each treatmental plot. The number of days taken for 50 per cent graft sprouting from the date of grafting were calculated and expressed in number of days.

\section{Percentage of graft sprouting}

The number of grafts sprouted successfully in each treatment was counted in each treatmental plot and expressed in percentage by using the following formula.

Number of sprouted grafts

$\%$ of graft sprouting = ----------------- X100

Total number of grafts

\section{Number of flushes per sprout}

The number of flushes per sprout in each treatment was counted at 15 days interval starting from $30^{\text {th }}$ DAG to $120^{\text {th }}$ DAG for five randomly selected grafts in each replication.

The average number of flushes per sprout were calculated and expressed in number.

\section{Percentage of graft survival}

The graft success was observed daily from the date of grafting to 120 DAG during the experimental period. The number of successful grafts were counted and recorded at $120^{\text {th }}$ DAG in each plot. The percentage of graft survival was calculated by employing the following formula as suggested by Mahendra et al., (2015) in guava within the growing conditions.

Number of grafts survived

Graft survival $(\%)=$---------------------- X100

Total number of grafts 


\section{Results and Discussion}

The present study reveals that the interaction between wedge grafting time and growing conditions differed significantly with respect to number of days taken for $50 \%$ of graft sprouting and per cent of graft sprouting. The minimum number of days (16.33) for $50 \%$ of graft sprouting was recorded in the plants grafted in January month followed by February month (20.07 days) grown under shade net condition whereas, the maximum number of days for $50 \%$ of graft sprouting (44.00) was recorded in plants grafted under poly house condition followed by grafts grown under shade net condition (42.33 days) plants grafted in September month.

The plants grafted in the month of January grown under shade net condition recorded the highest percentage of graft sprouting $(52.33 \%)$ whereas, the lowest $(0.33 \%)$ was recorded in grafts prepared during September month grown under poly house condition as shown in Table 1.

The data presented in Table 2 revealed that number of flushes per sprout i.e., 1.17, 1.32, $1.54,1.72,2.10,2.24$ and 2.31 at 30 , $45,60,75,90,105$ and 120 days after grafting (DAG) respectively was maximum in the grafts prepared during January month under shade net conditions and minimum of 0.52 , $0.62,0.85,1.02,1.17,1.37$ and 1.47 at 30 , $45,60,75,90,105$ and 120 days after grafting respectively was recorded in the grafts prepared during September month under poly house condition.

The data presented in Table 3 revealed that highest percentage of graft survival $(60.10 \%)$ was recorded in plants grafted during January month followed by February month (46.78\%) under shade net condition at 120 DAG. The lowest percentage of graft survival $(3.35 \%)$ was recorded in grafts prepared during September month under poly house condition.
A perusal of the data revealed that, minimum number of days taken for $50 \%$ of graft sprouting (29.80 days), maximum percentage of graft sprouting (18.57\%), number of flushes per sprout (2.10) were recorded in plants grafted under shade net condition when compared to the plants grafted under poly house condition and also the maximum percentage of graft sprouting (39.35\%), less number of days taken for $50 \%$ of graft sprouting (20.67 days) and number of flushes per sprout (2.17) were also recorded in the plants grafted during January month followed by December month (Fig. 2a, b).

It could be due to presence of favorable climatic conditions (i.e. mean maximum $\left(32.30^{\circ} \mathrm{C}\right)$, mean minimum $\left(24.68^{\circ} \mathrm{C}\right)$ temperatures and mean maximum (75\%), mean minimum $(42 \%)$ humidity encouraged the differentiation of mature parenchymatous cells into cambial tissue between stock and scion due to production of auxins at wounding site induced the early sprouting of grafts.

The earlier formation of cambial tissue between stock and scion increased the percentage of graft sprouting and development of new flushes on the sprout (Taiz and Zeiger, 2012).

These results are in agreement with the findings of Adjei et al., (2005) in avocado; Baskaran et al., (2008) in jackfruit; Aralikatti et al., (2011) in jamun; Kalalbandi et al.,(2014) in Sapota; Munthaj (2014) in guava and Sivudu et al., (2014) in mango.

The highest percentage of graft survival could be due to presence of congenial environmental conditions during January and December months. The prevailing favourable climatic conditions encouraged the production of auxins and conversion of mature parenchymatous cells into cambial cells leads to the development of successful graft union between the stock and scion. 
Fig.1 Sequential steps of wedge grafting in guava
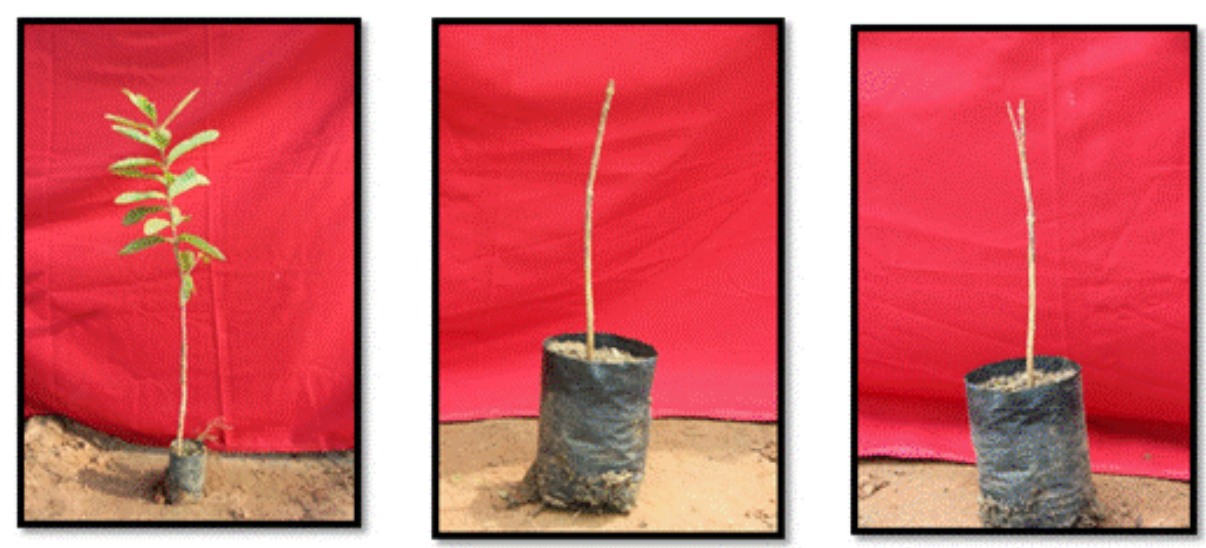

1. Selected rootstock

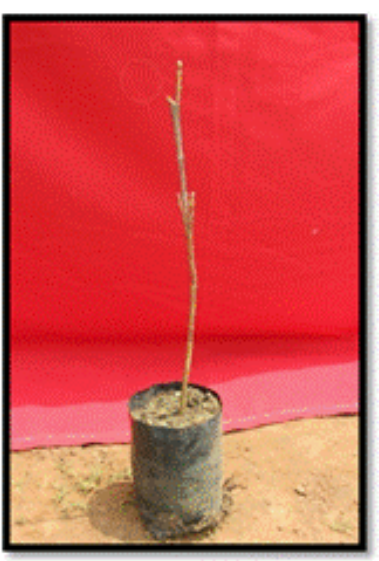

6. Insertion of scion on to the rootstock
2. Beheaded rootstock

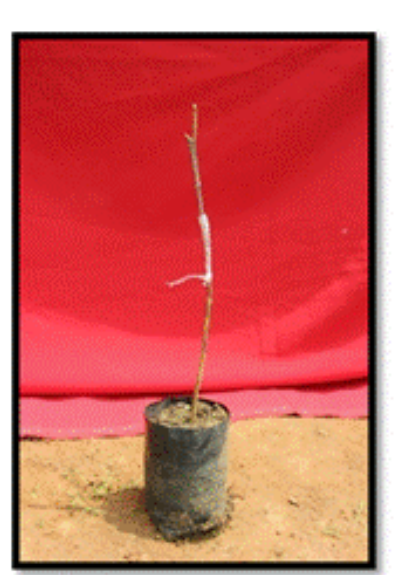

7. Graft union tied with 8.Scion stick covered polythene tape

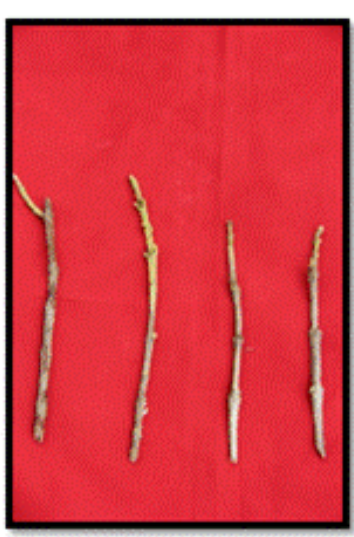

4. Precured scions

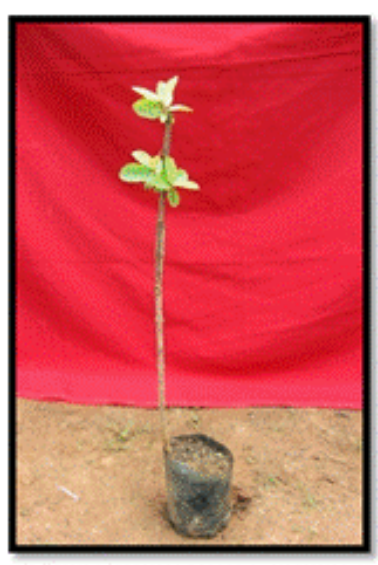

9.Sprouted graft

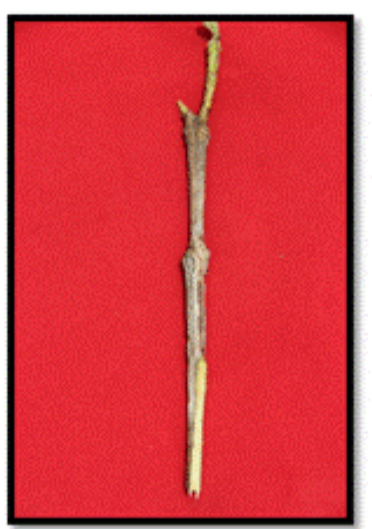

5. Prepared scion for grafting

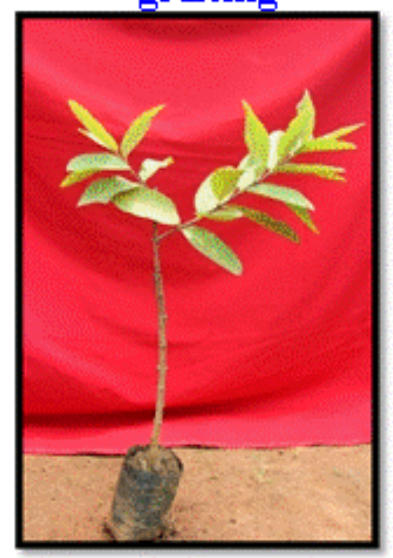

10. Successful graft 


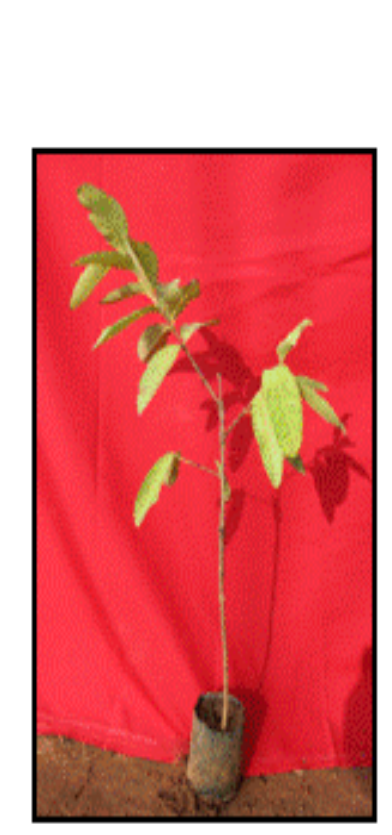

Shade net
August

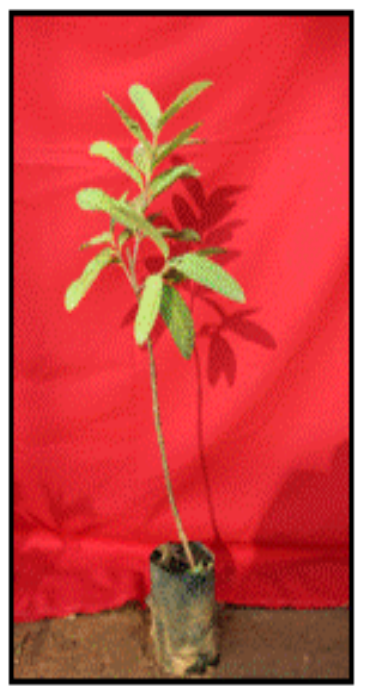

Poly house
September

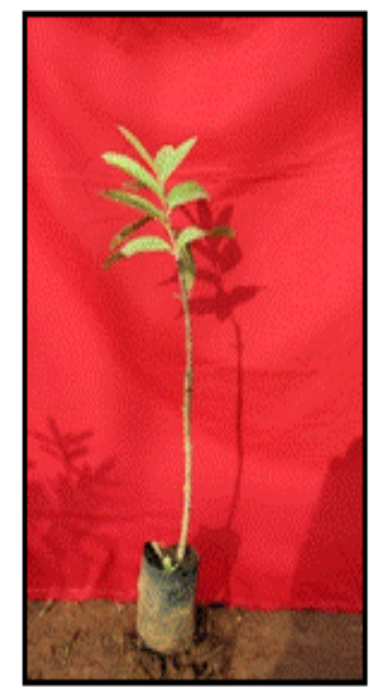

Shade net

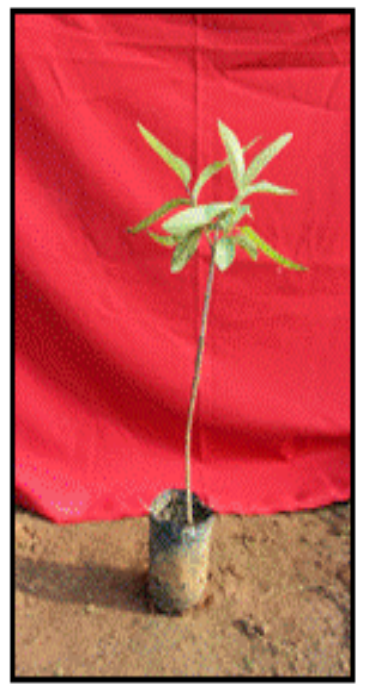

Poly house
October

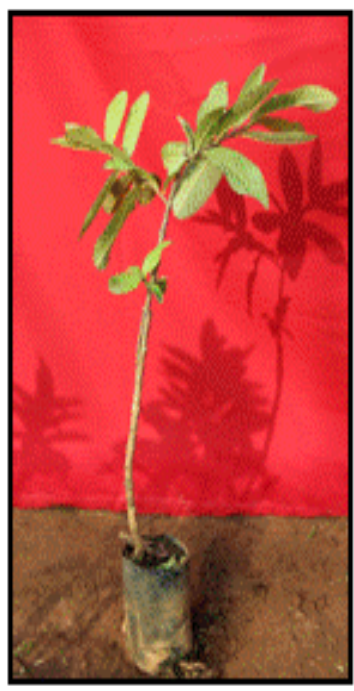

Shade net

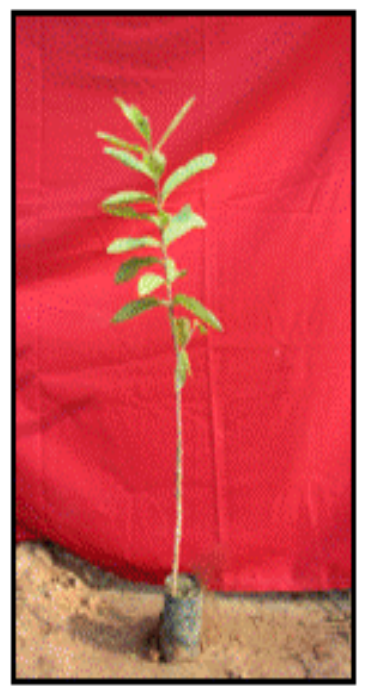

Poly house

Figure.2a Effect of different growing conditions and time of grafting on growth and success of grafts at 120 days after grafting 
Fig.2b Success of grafts at 120 days after grafting

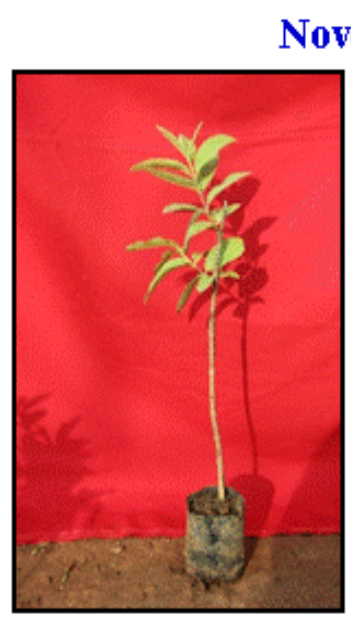

Shade net

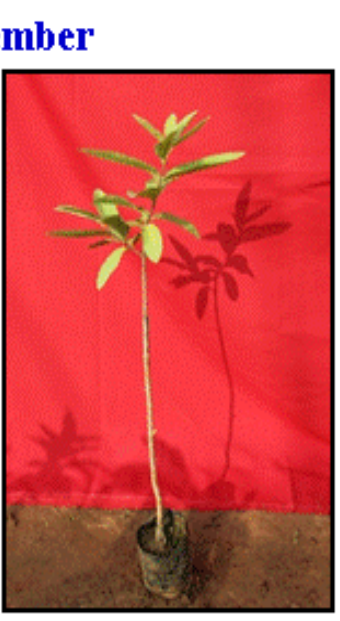

Poly house
December

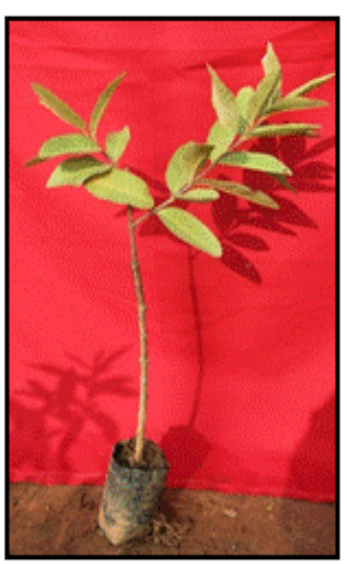

Shade net
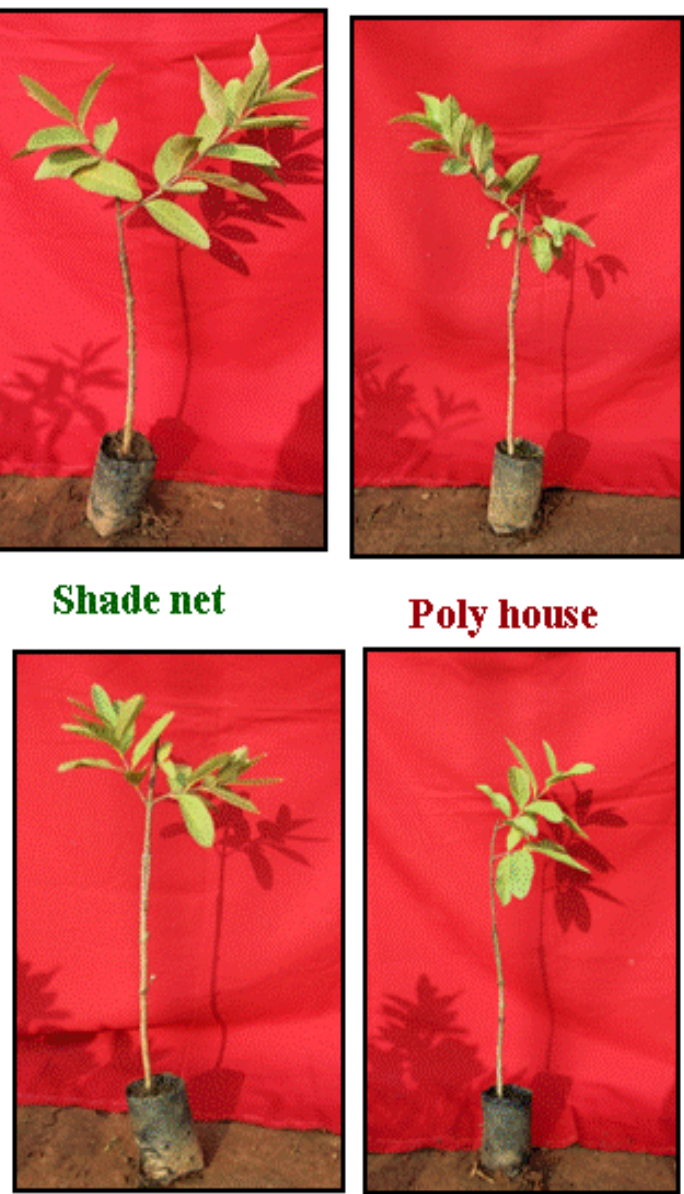

Poly house

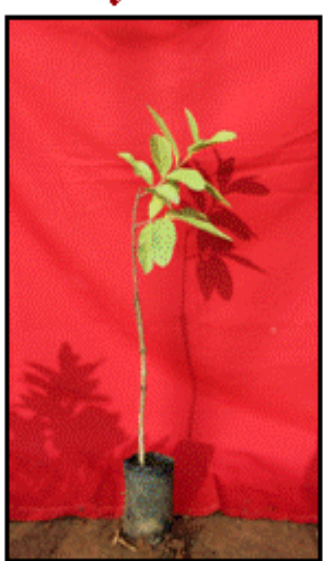

February

Figure. 2b Effect of different growing conditions and time of grafting on growth and success of grafts at 120 days after grafting
January

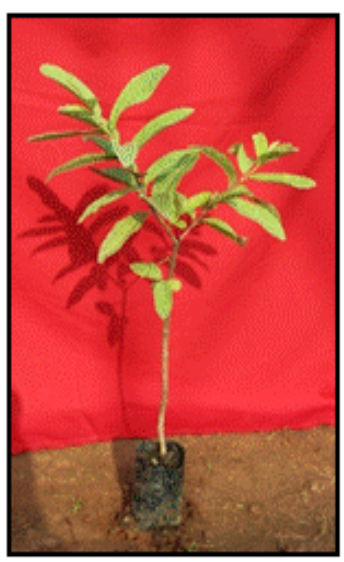

Shade net

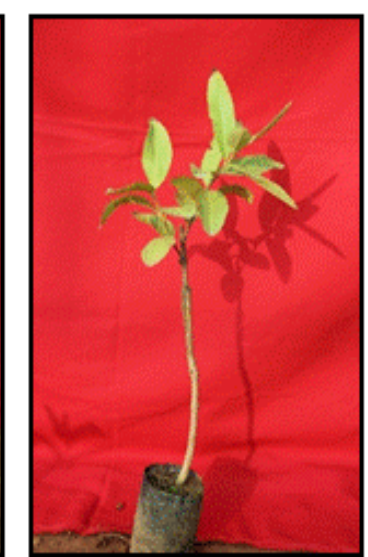

Poly house 
Table.1 Effect of growing conditions, time of wedge grafting and their interaction on number of days taken for 50 per cent of graft sprouting and percentage of graft sprouting in guava

\begin{tabular}{|c|c|c|c|c|c|c|c|c|}
\hline \multirow{3}{*}{$\begin{array}{c}\text { Treatments } \\
M_{1}\end{array}$} & \multicolumn{3}{|c|}{ Number of days taken for 50 per cent of graft sprouting } & \multicolumn{5}{|c|}{ Percentage of graft sprouting } \\
\hline & \multirow{2}{*}{$\begin{array}{c}\mathbf{C}_{1} \\
33.93\end{array}$} & \multirow{2}{*}{$\begin{array}{c}\mathbf{C}_{2} \\
28.33 \\
\end{array}$} & \multirow{2}{*}{$\begin{array}{r}\text { Mean } \\
31.13\end{array}$} & $\mathrm{C}_{1}$ & \multicolumn{2}{|c|}{$\mathrm{C}_{2}$} & \multicolumn{2}{|c|}{ Mean } \\
\hline & & & & $5.80 \quad(13.91)^{*}$ & 22.50 & $(28.30)$ & 14.15 & $(\mathbf{2 1 . 1 0})$ \\
\hline $\mathbf{M}_{2}$ & 42.33 & 44.00 & 43.17 & $0.33 \quad(1.91)$ & 0.33 & $(1.91)$ & 0.33 & (1.92) \\
\hline $\mathbf{M}_{3}$ & 37.00 & 38.33 & 37.67 & $5.20 \quad(3.11)$ & 2.17 & $(8.44)$ & 3.68 & $(\mathbf{1 0 . 7 7})$ \\
\hline $\mathbf{M}_{4}$ & 31.20 & 41.00 & 36.10 & $11.00 \quad(19.35)$ & 0.90 & $(5.43)$ & 5.95 & (12.39) \\
\hline $\mathbf{M}_{5}$ & 27.77 & 23.30 & 25.53 & $\begin{array}{ll}25.00 & (29.98)\end{array}$ & 29.00 & $(32.56)$ & 27.00 & $(31.27)$ \\
\hline$M_{6}$ & 16.33 & 25.00 & 20.67 & $52.33 \quad(46.32)$ & 26.37 & $(30.88)$ & 39.35 & (38.60) \\
\hline $\mathbf{M}_{7}$ & 20.07 & 38.17 & 29.12 & $30.33 \quad(33.38)$ & 1.17 & $(6.16)$ & 15.75 & (19.77) \\
\hline \multirow[t]{2}{*}{ Mean } & 29.80 & 34.02 & & (22.64) & 11.78 & (16.24) & & \\
\hline & SE(m) & \multicolumn{2}{|c|}{ C.D (5\%) } & SE(m) & \multicolumn{4}{|c|}{ C.D (5\%) } \\
\hline Factor -1 & 0.36 & \multicolumn{2}{|r|}{1.05} & 0.26 & \multicolumn{4}{|c|}{0.77} \\
\hline Factor -2 & 0.67 & \multirow{2}{*}{\multicolumn{2}{|c|}{$\frac{1.96}{2.77}$}} & 0.49 & \multirow{2}{*}{\multicolumn{4}{|c|}{$\begin{array}{l}1.45 \\
2.04\end{array}$}} \\
\hline Interaction $(1 \times 2)$ & 0.95 & & & 0.70 & & & & \\
\hline \multicolumn{9}{|c|}{ (*Figures in the parenthesis are angular transformed values) } \\
\hline \multicolumn{2}{|l|}{ Factor -1} & $\mathrm{C}_{1}=$ Shade net & \multicolumn{2}{|l|}{$\mathrm{C}_{2}=$ Polyhouse } & & & & \\
\hline \multirow[t]{2}{*}{ Factor -2} & & $M_{1}=$ August & $M_{2}=$ September & \multirow{2}{*}{$\begin{array}{l}M_{3}=\text { October } \\
M_{7}=\text { February }\end{array}$} & & \multicolumn{3}{|c|}{$M_{4}=$ November } \\
\hline & & $M_{5}=$ December & $M_{6}=$ January & & & & & \\
\hline
\end{tabular}

Table.2 Effect of growing conditions, time of wedge grafting and their interaction on number of flushes per sprout in guava

\begin{tabular}{|c|c|c|c|c|c|c|c|c|c|c|c|c|c|c|c|c|c|c|c|c|c|}
\hline \multirow{3}{*}{ Treatments } & \multicolumn{21}{|c|}{ Number of flushes per sprout } \\
\hline & \multicolumn{3}{|c|}{30 DAG } & \multicolumn{3}{|c|}{45 DAG } & \multicolumn{3}{|c|}{60 DAG } & \multicolumn{3}{|c|}{75 DAG } & \multicolumn{3}{|c|}{90 DAG } & \multicolumn{3}{|c|}{105 DAG } & \multicolumn{3}{|c|}{120 DAG } \\
\hline & $\mathrm{C}_{1}$ & $\mathbf{C}_{2}$ & Mean & $\mathrm{C}_{1}$ & $\mathbf{C}_{2}$ & Mean & $\mathbf{C}_{1}$ & $\mathbf{C}_{2}$ & Mean & $\mathbf{C}_{1}$ & $\mathrm{C}_{2}$ & Mean & $\mathrm{C}_{1}$ & $\mathbf{C}_{2}$ & Mean & $\mathrm{C}_{1}$ & $\mathbf{C}_{2}$ & Mean & $\mathrm{C}_{1}$ & $\mathrm{C}_{2}$ & Mean \\
\hline $\mathbf{M}_{1}$ & 0.80 & 1.10 & 0.95 & 0.89 & 1.12 & 1.01 & 1.18 & 1.40 & 1.29 & 1.32 & 1.57 & 1.45 & 1.47 & 1.78 & 1.63 & 1.82 & 2.06 & 1.94 & 1.95 & 2.15 & 2.05 \\
\hline $\mathbf{M}_{2}$ & 0.58 & 0.52 & 0.55 & 0.67 & 0.62 & 0.65 & 0.92 & 0.85 & 0.89 & 1.11 & 1.02 & 1.11 & 1.24 & 1.17 & 1.21 & 1.46 & 1.37 & 1.42 & 1.57 & 1.47 & 1.52 \\
\hline $\mathbf{M}_{3}$ & 0.77 & 0.72 & 0.75 & 0.86 & 0.82 & 0.84 & 1.12 & 1.09 & 1.11 & 1.28 & 1.24 & 1.26 & 1.42 & 1.37 & 1.40 & 1.78 & 1.72 & 1.75 & 1.87 & 1.83 & 1.85 \\
\hline $\mathbf{M}_{4}$ & 0.85 & 0.61 & 0.73 & 0.93 & 0.71 & 0.82 & 1.22 & 0.99 & 1.10 & 1.37 & 1.15 & 1.26 & 1.53 & $\begin{array}{l}1.27 \\
\end{array}$ & 1.40 & 1.86 & 1.55 & 1.70 & 1.98 & 1.72 & 1.85 \\
\hline $\mathbf{M}_{5}$ & 0.94 & 1.06 & 1.00 & 0.99 & 1.21 & 1.10 & 1.31 & 1.45 & 1.38 & 1.47 & 1.65 & 1.56 & 1.62 & 1.90 & 1.80 & 1.97 & 2.18 & 2.07 & 2.08 & 2.20 & 2.13 \\
\hline $\mathbf{M}_{6}$ & 1.17 & 0.88 & 1.03 & 1.32 & 0.96 & 1.14 & 1.54 & 1.27 & 1.41 & 1.72 & 1.42 & 1.57 & 2.10 & 1.58 & 1.84 & 2.24 & 1.91 & 2.13 & 2.31 & 2.02 & 2.17 \\
\hline $\mathbf{M}_{7}$ & 0.98 & 0.67 & 0.83 & 1.05 & 0.77 & 0.91 & 1.36 & 1.03 & 1.20 & 1.52 & 1.19 & 1.35 & 1.65 & 1.32 & 1.5 & 2.03 & 1.68 & 1.86 & 2.10 & 1.77 & 1.94 \\
\hline \multirow[t]{2}{*}{ Mean } & 0.87 & 0.79 & & 0.96 & 0.89 & & 1.24 & 1.15 & & 1.40 & 1.32 & & 1.60 & 1.49 & & 1.88 & 1.78 & & 2.1 & 1.87 & \\
\hline & SE(m) & \multicolumn{2}{|c|}{ C.D (5\%) } & SE(m) & \multicolumn{2}{|c|}{ C.D (5\%) } & SE(m) & \multicolumn{2}{|c|}{ C.D (5\%) } & $\mathrm{SE}(\mathrm{m})$ & \multicolumn{2}{|c|}{ C.D (5\%) } & SE(m) & \multicolumn{2}{|c|}{ C.D (5\%) } & SE(m) & \multicolumn{2}{|c|}{ C.D (5\%) } & SE(m) & \multicolumn{2}{|c|}{ C.D (5\%) } \\
\hline Factor $-\mathrm{C}$ & 0.01 & \multicolumn{2}{|c|}{0.02} & 0.003 & & & 0.002 & \multirow{2}{*}{\multicolumn{2}{|c|}{$\begin{array}{l}0.01 \\
0.01 \\
\end{array}$}} & 0.002 & \multirow{2}{*}{\multicolumn{2}{|c|}{$\begin{array}{l}0.01 \\
0.01\end{array}$}} & 0.01 & \multicolumn{2}{|c|}{0.02} & 0.01 & \multirow{2}{*}{\multicolumn{2}{|c|}{$\begin{array}{l}0.02 \\
0.03\end{array}$}} & 0.003 & \multirow{2}{*}{\multicolumn{2}{|c|}{$\begin{array}{l}0.01 \\
0.01\end{array}$}} \\
\hline Factor $-\mathbf{M}$ & 0.01 & & & 0.005 & & & 0.01 & & & 0.01 & & & 0.01 & & & 0.01 & & & 0.01 & & \\
\hline Interaction $(\mathbf{C} \times \mathbf{M})$ & 0.03 & \multicolumn{2}{|c|}{0.05} & 0.007 & \multicolumn{2}{|c|}{0.02} & 0.01 & \multicolumn{2}{|c|}{0.02} & 0.01 & \multicolumn{2}{|c|}{0.02} & 0.02 & \multicolumn{2}{|c|}{0.05} & 0.02 & \multicolumn{2}{|c|}{0.04} & 0.01 & & .02 \\
\hline & actor - & & & $\mathrm{C}_{1}=$ Sha & net & & & $\mathrm{C}_{2}=\mathrm{Po}$ & lyhous & & & & & & & & & & & & \\
\hline & actor - & & & $\mathbf{M}_{1}=\mathbf{A l}$ & & & & $\mathbf{M}_{2}=\mathbf{S}$ & ptemb & & & $\mathbf{M}_{3}$ & Octobe & & & & $=$ Nove & mber & & & \\
\hline & & & & $\mathrm{M}_{5}=\mathrm{De}$ & mber & & & $\mathbf{M}_{6}=\mathbf{J}$ & inuary & & & $\mathbf{M}_{7}=$ & Februa & & & & & & & & \\
\hline
\end{tabular}


Table.3 Effect of growing conditions, time of wedge grafting and their interaction on percentage of graft survival in guava

\begin{tabular}{|c|c|c|c|}
\hline \multirow{3}{*}{ Treatments } & \multicolumn{3}{|c|}{ At 120 Days after grafting } \\
\hline & \multicolumn{3}{|c|}{ Percentage of graft survival } \\
\hline & $\mathbf{C}_{1}$ & $\mathbf{C}_{2}$ & Mean \\
\hline $\mathbf{M}_{1}$ & $16.68(24.09)^{*}$ & $30.13 \quad(33.27)$ & $23.40 \quad(28.68)$ \\
\hline $\mathbf{M}_{2}$ & $3.35 \quad(10.53)$ & $3.35 \quad(10.54)$ & $3.35 \quad(10.53)$ \\
\hline $\mathbf{M}_{3}$ & $13.36 \quad(21.42)$ & $3.35 \quad(10.54)$ & $8.36 \quad(15.98)$ \\
\hline $\mathbf{M}_{4}$ & $23.36 \quad(28.88)$ & $6.68 \quad(14.96)$ & $15.02 \quad(21.92)$ \\
\hline $\mathbf{M}_{5}$ & $33.36 \quad(35.26)$ & $43.35 \quad(41.16)$ & $38.36 \quad(38.21)$ \\
\hline $\mathbf{M}_{6}$ & $60.10 \quad(50.81)$ & $26.68 \quad(31.08)$ & $43.39 \quad(40.94)$ \\
\hline $\mathbf{M}_{7}$ & $46.78 \quad(43.13)$ & $10.17 \quad(18.59)$ & $28.48 \quad(30.86)$ \\
\hline \multirow[t]{2}{*}{ Mean } & $28.14 \quad(30.59)$ & $17.67 \quad(22.88)$ & \\
\hline & SE(m) & C.D (5\%) & \\
\hline Factor -1 & 0.01 & 0.04 & \\
\hline Factor -2 & 0.03 & 0.08 & \\
\hline Interaction $(1 \times 2)$ & 0.04 & 0.11 & \\
\hline
\end{tabular}

(*Figures in the parenthesis are angular transformed values)

\begin{tabular}{|l|l|l|l|l|}
\hline Factor -1 & $\mathbf{C}_{1}=$ Shade net & $\mathbf{C}_{2}=$ Polyhouse & & \\
\hline Factor -2 & $\mathbf{M}_{1}=$ August & $\mathbf{M}_{2}=$ September & $\mathbf{M}_{3}=$ October & $\mathbf{M}_{4}=$ November \\
\hline & $\mathbf{M}_{5}=$ December & $\mathbf{M}_{6}=$ January & $\mathbf{M}_{7}=$ February & \\
\hline
\end{tabular}

The development of cambial tissues between stock and scion encouraged the early graft sprouting, percentage of sprouting, number of flushes per sprout, helps in better establishment of the grafts. This helps in uptake of more water and nutrients from the soil, synthesized more photosynthates and auxins in the leaves thereby increased the transport of water, nutrients, photosynthates and hormones to the newly developed scion shoot, increased the success of graft survival (Taiz and Zeiger, 2012). These results are in agreement with the findings of Anushma et al., (2014) in jamun; Kalabandi et al., (2014) in sapota and Sivudu et al., (2014) in mango.

On the basis of results obtained from the present investigation, it can be concluded that the best results were obtained in the plants grafted during January month under shade net condition is more favorable for better success rate and better graft survival percentage.

\section{Acknowledgement}

We are thankful to the Department of Fruit science, Horticultural College and Research Institute, Venkataramannagudem, Dr. YSRHU, West Godavari District, Andhra Pradesh, for providing their valuable services and helping us for the successful completion of our project.

\section{References}

Adjei, P.Y., Boateng, P.Y. and Okyere, Y. 2005. Studies of three grafting methods of propagating Avocado (Persea americana).Ghana Jour. of Hort. 4:5259.

Anushma, P.L., Swamy, G.S.K. and Gangadhara, K. 2014. Effect of colored shade nets on softwood grafting success in jamun (Syzigium cuminii skeels). Plant Archives. 14(1): 293-95. 
Aralikatti, G., Mokashia, A.N., Hedge, R.V, Patil, R.V. and Angadi, S.G. 2011. Softwood grafting in jackfruit. Acta Hort. 890:101-106.

Baskaran, A.S., Saraswathy and Parthiban, S. 2008. Standardization of propagation methods for jack (Artocarpus heterophyllus, Lam). The Asian J. of Hort. 3(2): 361-63.

Kalalbandi, B.M., Ziauddin, S., and Shinde, B.N. 2014. Effect of time of soft wood grafting on the success of sapota grafts in $50 \%$ shade net under Marathwada conditions. Agri. Sci. Digest. 34(2):15153.

Mahendra, J., Yogesh, S., Singh, S.S. and Mishra, S.P. 2015. To Study the suitable period of wedge grafting in guava under different condition of Chitrakoot Region. American Int. J. of Research in Formal, Appl. Natural Sci. 9(1):30-32.

Munthaj, 2014. Studies on improvement of seed germination and season of wedge grafting in guava (Psidium guajava L.). M.Sc Thesis. Horticultural College and Research Institute, Dr. Y.S.R. Horticultural University. Anantharajupet, Dr. Y.S.R. Kadapa district, Andhra Pradesh.

Singh, G., Gupta, S., Mishra, R. and Singh, G.P. 2005. Wedge grafting in guava - A novel vegetative propagation technique, Central Institute for Sub- tropical Horticulture, Lucknow, 12.

Sivudu, B.V., Reddy, M.L.N., Baburatan, P., and Dorajeerao, A.V.D. 2014. Effect of structural conditions on veneer grafting success and survival of mango grafts (Mangifera indica $c v$. Banganpalli). Plant Archives. 14(1):71-75.

Taiz, L., and Zeiger, E. 2012.Text book of plant physiology. Fifth edition. Published by sinauer associate Inc publishers. Sunderland. Massachusetts. USA. 546-580.

\section{How to cite this article:}

Vanaja, L., D.V. Swami, B. Prasanna Kumar and Subbaramamma, P. 2017. Effect of Grafting Time on Growth and Success Rate of Guava (Psidium guajava L.) Wedge Grafts Grown under Shade Net and Poly House Conditions. Int.J.Curr.Microbiol.App.Sci. 6(10): 771-779. doi: https://doi.org/10.20546/ijcmas.2017.610.093 